\title{
nature
}

\section{Awash with cash, bereft of leadership}

The National Institutes of Health has been granted impressive funding increases, but its lack of a permanent director is getting beyond a joke. The sooner the Bush administration plugs this gap with an inspired leader, the better.

$\mathrm{O}$ ne of the most momentous features of the federal budget proposal released this week by President George W. Bush (see pages 564-565) is its inclusion of funds that complete a doubling in funding for the National Institutes of Health (NIH), from some US\$13.6 billion in 1998 to US\$27.3 billion in 2003.

If, as expected, this request is endorsed by the US Congress, it will constitute a remarkable victory for the researchers, medical schools, patient advocacy groups and drug companies that have lobbied for this objective. It is unfortunate, however, that this immense build-up at the biomedical research agency is reaching its climax during a prolonged period in which it has had no permanent director.

The NIH director's office has become a politically sensitive spot, as issues surrounding embryo and fetal research embroil the agency in US abortion politics. That made it tough for President Bill Clinton to replace Harold Varmus, the former NIH director, when he vacated the post in December 1999. Given the political sensitivity of these issues, anyone taking the job would have been unsure whether their tenure would survive a change of occupant at the White House.

When Bush was elected, an early effort was made to fill the position, without success. One year on, the strain is now beginning to show. Ruth Kirschstein, the acting director of the NIH, has a unique mastery of the agency's workings - the product of a quarter-century of experience in its higher echelons. But although that has equipped her well to run a holding operation, Kirschstein would be the last person to suggest that she has the profile to fill Varmus's shoes on a permanent basis.

Any large institution requires inspired leadership. Awash with money it may be, but in a number of important respects the NIH is adrift. Major strategic projects, including the completion of the new clinical research centre at the agency's Bethesda campus and the closing stages of the Human Genome Project, require the overview and input of a permanent NIH director. Varmus also worked hard to restore the scientific vitality of the NIH's intramural programme at Bethesda, which accounts for some $10 \%$ of the agency's budget, and attracted several top names to the campus. But some of these people have now left, without being replaced. The director of the NIH, had there been one, would also have played a major role in reassuring the public that the best science was being used to counter bioterrorism, in the wake of the anthrax attacks in the United States last autumn.

Perhaps the biggest problem, however, is that the directorship is vacant at a time when Tommy Thompson, head of the NIH's parent body, the Department of Health and Human Services, is working to expand his influence over the research agency's activities. It is understandable that Thompson, a former state governor, wants a say in running his department's crown jewel. But it seems to have escaped his attention that the NIH has attained this status precisely because it has avoided the politicization of its programmes and the bureaucratization of its operations that blight many US government agencies.

In his thinly disguised power grab for authority over such sundry matters as travel policy and press and congressional relations at $\mathrm{NIH}$ institutes, Thompson has turned what ought to be a time of great vision and opportunity at the NIH into a period of unseemly niggling and infighting. Various excuses have been quietly voiced for the failure of Thompson and the Bush administration to find a leader for the NIH. But with Bush's policy on embryonic stem cells in place and the administration into its second year, it is way past time for them to name an NIH director of stature, who will ensure that its incredible expansion is managed effectively and imaginatively.

\section{A troublesome ménage à trois}

\section{France's largest research agency is in need of reform - but so are the universities that host its labs.}

W ith 25,000 staff working in every area of science, the CNRS is the emblem of French research. So when the country's premier auditing body states that all is not well with the agency, those involved should sit up and listen.

The auditors' report charges that the CNRS - which gets 2.4 billion euros (US $\$ 2.1$ billion) of public funding annually — has had no strategic plan for the past six years (see page 563). On paper, this is undeniable, although to be fair to the CNRS, its lack of strategic direction owes as much to a repeated buffeting from successive politicians seeking to make their mark on the agency as to the CNRS's own failings.

The good news is that the agency's governing board this week endorsed a plan that correctly identifies the thorny issues - such as poor mobility and lack of autonomy for young scientists - that lie at the root of the CNRS's problems. The question is whether this plan can be translated into action.

The CNRS has long been caught in an unhappy ménage à trois between the universities, which host its labs, and its paymaster, the research ministry. If French science is to be freed from this tug-oflove, each partner needs a better-defined role.

Addressing this problem should be a top priority for the new research minister who will be appointed following the parliamentary elections in June. With half of the country's scientists due to retire over the next decade or so, the minister will have an unprecedented opportunity to reshape France's research system.

Equally important to revitalizing the CNRS, and perhaps more challenging, will be the need to get the universities to address the twin themes of mobility and autonomy, and to lessen the teaching demands on top university scientists. Only then can the universities and CNRS labs begin to interact in a more productive way. 